\title{
Unplugging Diana's E-Newsletter at Island Associates
}

\author{
Joseph Trainor \\ Long Island University \\ Barry Armandi \\ SUNY-Old Westbury \\ Herbert Sherman \\ LIU-Southampton College
}

\begin{abstract}
*
Derived from personal observation, the case describes how the tripling of a newsletter distribution by email causes havoc for Island Associates. The case begins by describing Island Associates (IA) as small but rapidly growing energy consulting firm based on Long Island, New York. One of the newest services proposed to keep their clients up-to-date with industry trends, as well as serve in a promotional capacity, was a bi-monthly newsletter. The first emailing of 1000 announces incurred no technical problems and the newsletter received positive feedback from the customers. An expansion of the mailing to 1500 addresses merely slowed the server a bit for several hours in the next go round so it was decided that a full emailing (3000 emails) should be sent. This mailing, however, caused numerous problems for both the clients and LA. Some clients were receiving numerous copies while others received none. Email returns based upon "information overflow" generated nearly 27,000 messages and required the shutting down of the company's server. The case ends with the CEO calling a meeting to deal not only with this immediate emergency but to also deal with the ramifications of the email problem (customer relations, future of newsletter).

\section{Introduction}

"What a fiasco!" yelled Rich Hammond, CEO of Island Associates, to Steve Smith, Chief Marketing Officer. "Our clients are screaming at us for tying up their information systems. We better have an answer for them and quick. Call the group together, I want to get to the bottom of this and find out what we should do. Over 27,000 emails..." he continued shaking his head.
\end{abstract}

\section{Background}

Island Associates, Inc. was an economic and management consulting firm specializing in energy and utility matters. Throughout Island's history, they assisted clients in such mission-critical areas as: economic and financial analysis; strategic management and marketing services; industry restructuring support; litigation and regulatory support; technical analysis; and implementation support. 
Island delivered value through the application of first-hand industry expertise, strong implementation capabilities, thought leadership, and a team-based philosophy that facilitated the transfer of knowledge to their clients. Island's clients encompassed the full range of the energy value chain. The clientele spanned all market sectors including energy producers, the financial community, the legal and regulatory community, new business ventures, and energy intensive consumers. Over the years, Island was called upon to provide expert testimony before state, Federal, and Provincial regulatory commissions, as well as civil and bankruptcy courts in the U.S. and Canada. In all, since 1981 they served more than 300 clients worldwide.

Island's professionals included experienced energy company senior executives, energy economists, senior policy experts and regulatory officials, engineers, renowned futurists, and internationally respected subject matter experts. Many of these professionals were widely published. Each was highly regarded for his or her unique insight and targeted approach to problem solving.

Island grew from a single office on Long Island with 5 employees, to over 35 employees in multiple offices in New York, Washington DC, Houston, Atlanta, Maine and San Francisco. In 2001, the Company had a little over $\$ 5$ million in sales and a net profit of $\$ 425,000$. Cost of Goods Sold was $\$ 3.3$ million. Their total assets were $\$ 2.2$ million with $\$ 1.2$ million in accounts receivable. Total liabilities were $\$ 1.2$ million with $\$ 400,000$ in accruals.

\section{The Newsletter}

Steve Smith, the Chief Marketing Officer for Island (See Exhibit I for Island's Organizational Chart), wanted to get a greater profile for the Company, especially before its clients. The idea was to create the Island Restructuring Report. This Report, which is nothing more than a Newsletter, tracked the activities of those leading and emerging energy industry companies. Every two weeks the Report provided brief summaries of news items relating to mergers and acquisitions, new company formations, new entrants into the energy sector, new senior management appointments, independent transmission company development, merchant generation development, and natural gas industry development.

Steve pitched his idea to Joe Clark, Chief Operating Officer and Rich Hammond, Chief Executive Officer. Steve indicated that it would be a no or low cost way to keep in contact with the existing client base by giving them information they needed in a quick and easy format. Steve would cut and paste information from various public news sources and combine them in one document with the Company's logo. Also included would be other Company references like phone numbers and email addresses.

Rich and Joe enthusiastically approved the idea and John Mentor was asked to create a way to dump their current client database into a list that would be copied into the address line of an email. Diana Mullens was approached by Steve to maintain this list and Diana delegated this task to Jan Collins. John created the list in Excel so it could 
be easily sorted and reviewed. This action was essential since it enabled the Company to add new names or remove clients who objected to receiving the Newsletter via email. John showed Jan how to copy the Excel List into the BCC (Blind Carbon Copy) address line of an email and the first Newsletter was sent out on the following Monday without a problem.

\section{Exhibit I \\ Island Associates, Inc. Organizational Chart 2002}

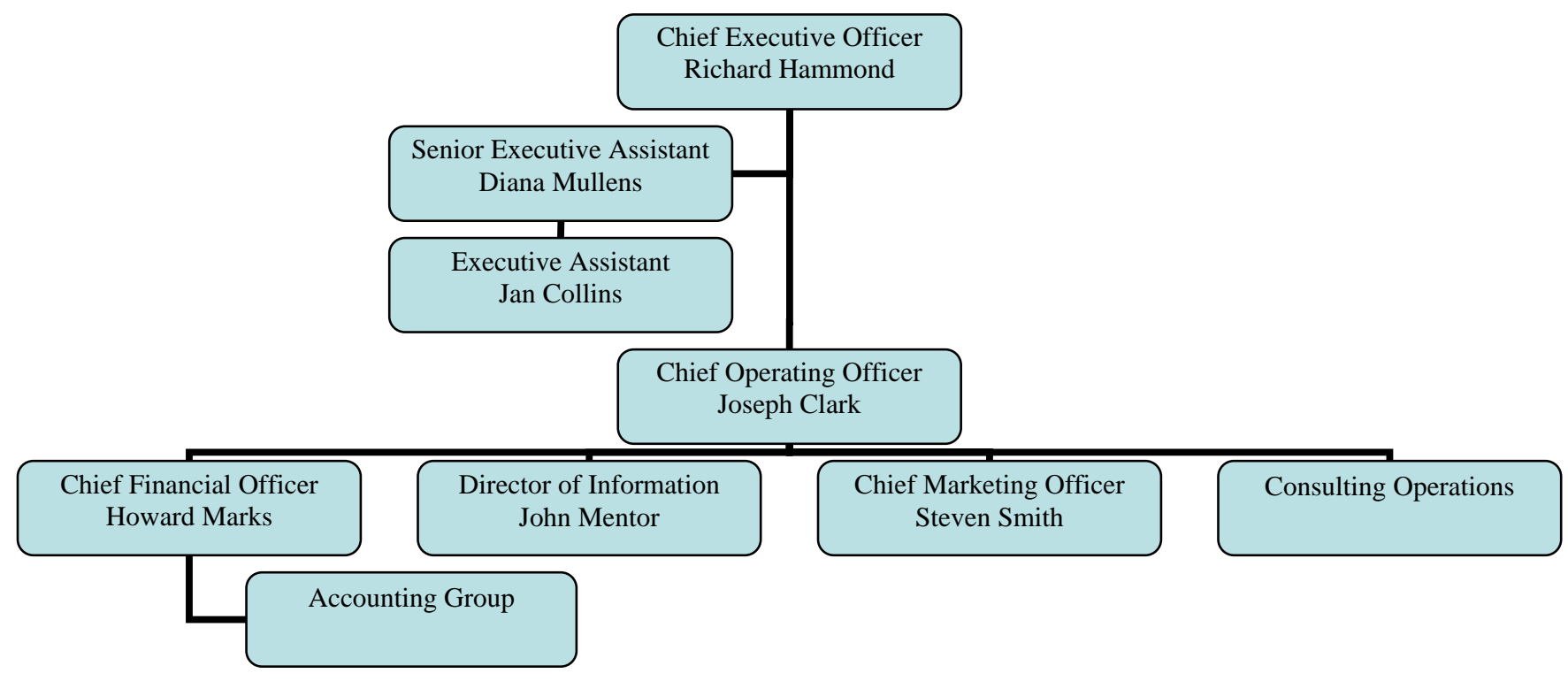

The Newsletter was a big success. It had no out of pocket cost, and was getting great reviews. The company received accolades and numerous requests for more copies to be sent to associates of clients.

\section{The Distribution Expands}

Steve, wanting to build on the success of the Newsletter, decided to expand the distribution of the Newsletter. Steve asked Jan to collect email addresses from various industry sources and enter them into the List. Steve then asked John if increasing the List from 1000 names to 3000 names could cause a problem for the email server. John said

"Yes! Even though only one email is sent out, the service provider splits that email into a thousand parts. So, for every email sent out that has an old or incorrect email address, we will get back about $700 \mathrm{k}$ of emails. This would bog down our email server and the Company would not be able to get to the Internet or receive other emails." 
John suggested that if Steve proceeded with this plan that they should send out the email after business hours to allow the server to handle the extra traffic at night.

With this information, Steve presented the idea to Joe and Rich, and was given permission to proceed. The List was expanded as fast as Jan could type, and on the next Monday at 6 o'clock the Newsletter email was sent to about 1500 people. The result was that the new mailing caused about 200 emails to return to the Company. These returned emails slowed down the server for about two hours, but there were no other problems.

\section{The Explosion}

On a Friday in July 2001, Jan reminded Diana that she would not be in on Monday. Diana would have to send out the Newsletter on Monday evening. Jan explained to Diana the procedure. She indicated that first, the body of the email from the last time the Newsletter was sent needed to be cut and pasted. Next, the file provided by Steve was to be attached. Lastly, Jan explained how to cut and paste the email addresses from Excel to the BCC line of the email. Diana replied, "This is a straight forward task and there should be no problems."

On Sunday, John boarded a plane for Kansas. He was scheduled to conduct a threeday work session for a client. Monday evening came and Diana followed Jan's instructions and sent the Newsletter out and left for the night.

Tuesday morning Diana came into work and was greeted by Jan asking, "Did everything go OK with the Newsletter last night?" Diana responded, "Yes, it went fine." Before Diana continued, Jan interrupted and informed her that there were a few calls from some clients about the email. They complained that they received multiple copies. With that, they went to Diana's computer to check on the number of replies received overnight. Earlier John told Diana to expect about 2 or 3 hundred bad email addresses from the 1500 new addresses Jan entered over the last two weeks. John also noted that it could be a little more, and if it was, not to worry, since he did not know how current the lists were from the various sources.

Jan and Diana were shocked when Diana's inbox had over 20,000 new emails. The shout of "OH MY GOD" was heard in the next office suite. Diana immediately called John on his cell phone. She heard the phone ring a few times and then there was a disconnect. Unbeknown to Diana, John always turned off his cell phone when in a client meeting. For some unknown technological reason, his voice mail did not answer the call. Once Diana realized that John was already at his meeting, she tried to call Rich. However, Rich also had a morning meeting and was not due until about 10:30 a.m. She then tried to get Steve. Steve, however, was at a client meeting in another part of the country. So she calmly told Jan to reboot the email server and tell anyone who called that Island had a problem and was trying to resolve it. Jan rebooted the server and continued to answer the numerous phone calls. 
At 10:30 a.m. Rich came into work and was greeted by Diana, who relayed the events of the past hour in 30 seconds. Rich asked Diana the following:

Rich: Are people still receiving new messages, or have they stopped?

Diana: People are still receiving messages.

Rich: Are we still receiving new auto replies?

Diana: Yes!

Rich: Have you rebooted the email server?

Diana: Yes!

Rich: Have you contacted John Mentor?

Diana: No, I can't get in touch with him. He is with a client.

Rich: When is he due to check back in with us?

Diana: Not until 1:00 p.m.

Rich told Diana to turn off the email server. Also she was to call all of the remote offices and tell them email was going to be down for a few hours. For the rest of the day, the New York Office personnel took calls and tried to explain that, "we were working on the problem." However, people were still getting more and more messages.

At 12:00 o'clock, Kansas' time, John broke from a four-hour meeting. He planned that the four participants from the meeting would go to a restaurant and continue the discussion about the meeting's topics. But first he needed to check messages.

John called the New York Office and Jan answered with a quick "Island Associates." John said, "Hello Jan, how did the Newsletter go last night?" In a strangely calm voice she said. "John, Diana is looking for you." John replied, "OK, transfer me over."

Diana explained the events of the past four hours in 45 seconds. John asked her to calmly start again from the top. At that point one of the clients walked in and John ask Diana to hold on for a minute. He advised the client that he would not be able to make lunch, since there was a problem at work that needed his immediate attention. The three clients left for lunch, and John told Diana he would call her back on the 800 number from a regular phone. John found a quiet room, a piece of paper and called the New York office. Diana picked up the phone on the first ring. John said, "Hello, I am sorry I cut you off, but this sounds serious and I wanted to get to a quiet place and call from a regular phone." John asked Diana the following:

John: How many replies did we get?

Diana: Over 20,000.

John: Are people still getting emails?

Diana: Yes, and we are getting more and more calls.

John: Can you open one of the responses and read it to me?

Diana: No, Rich told me to shut down the server.

John: Ok, Diana, the reason shutting down the server did not help is that we only send the message out once, and our provider breaks the message into its pieces 
and delivers them. Please, turn on the server. We need to see why these messages are bouncing.

She turned on the server and opened her email. She had about 23,000 messages and counting. Diana opened one of the messages and read it to John. The error message was: "Header overflow." Diana then offered this statement. "John, I copied the names into the CC address line of the email instead of the BCC address line. Could that be the cause of this problem?"

There was a long pause on the phone. Diana called out "John! John!" John knew exactly what the problem was. He should have seen it coming. He missed an important piece of information, and now he had to think of a resolution. He answered Diana by saying, "No, the fact that you copied the addresses into the CC is not causing this problem. But it could cause a different problem." He then asked Diana to open a few more emails and check if the errors were all "Header overflow." She checked a few more and they also said "Header overflow." After she opened a few more emails John heard nothing for a while. Then, over the phone, he heard a loud "OH MY GOD!" Jan came running into Diana's office, and he heard Diana explain to Jan, "People are responding that I must be a disgruntled employee. This one says I should be fired, and this one says I am laying on a beach somewhere, and look, they are all hitting the "Reply to All" button. Everyone on the email list is getting these messages."

With all the noise, John was still able to hear Rich's voice in the background. Knowing Diana was no longer going to be of any help, and knowing what the problem was, John asked Diana to transfer the call to Rich. Rich answered and John explained:

"An email header contains the addressing information and when we sent out the email with 3000 addresses it was more information then the email header could hold. So, when our provider's email server broke the email into its 3000 pieces, about half were being bounced back to us because they were beyond the limit of the header, and the other half was getting the message over and over again. The email server's internal processes should get a message that the email was sent successfully. If the internal email process does not get a successful message, it will resend the message until it does. However, Island's email server only sends one message out and we don't have control of the email anymore. "

At that point, the client returned and John's meeting was to reconvene. John recommended that since there was nothing that could be done right now, leave the email server on to monitor the situation. Also, disconnecting it would mean the company would have no email.

At five o'clock John called back and got Jan on the phone. She informed him that there were about 27,000 emails, but now they were mostly about Diana's life and her future. Jan also told John that Diana left at 2 o'clock, and that Rich was waiting for his call. Rich, got on the phone and said, "The problem is people are still getting the message, and we need to make it stop." John again told him it probably was not Island's server. 
Rich made the decision to shut down the server until John got back. John asked Rich whether he should stay in Kansas with the client, or should he fly back immediately? Rich told John to stay with the client. To be certain that it was not Island's email server, Rich ordered the server be turned off for those two days.

\section{The Meeting}

John got into New York at about 6:30pm Thursday night and headed right to the office. At that time, nobody was there. He spent most of the night rebuilding the email server. He found out that he was wrong and Island's server indeed was sending the message out over and over again. He left the office at about 3:30 A.M. Friday morning, and got back to work at 8:00 A.M. No sooner than he sat in his chair, his phone rang. It was Rich, who said, "John, please come to my office immediately. I'm with Steve and Joe and we want to sort out this email fiasco. Especially, how do we respond to our clients? What do we say? Do we ever send another Newsletter again?"

* This is a disguised case so names have been changed to provide confidentiality. For a copy of a detailed teaching note, please contact either Barry Armandi or Herbert Sherman. 